\title{
Pollen of Bauhinia L. and Phanera Lour. (Leguminosae-Caesalpinioideae) from the Brazilian Caatinga
}

\author{
Francisco de Assis Ribeiro dos Santos, Danovan de Matos Novaes, Luciano Paganucci de Queiroz
}

Programa de Pós-Graduação em Botânica, Universidade Estadual de Feira de Santana, Feira de Santana, Bahia, Brazil. Email: fasantos@uefs.br

Received April 13 ${ }^{\text {th }}, 2012$; revised May 18 ${ }^{\text {th }}, 2012$; accepted May 25 ${ }^{\text {th }}, 2012$

\begin{abstract}
A study of pollen morphology, in species of the genera Bauhinia and Phanera (Leguminosae-Caesalpinioideae) which occur in the Brazilian caatinga, is presented. The pollen was examined using light and scanning electron microscopy. Samples were prepared by the $\mathrm{KOH}$ method; non-treated pollen grains were examined by scanning electron microscopy. Pollen grains in Bauhinia species (11) are colpate, but porate in B. cheilantha and B. subclavata. All four species of Phanera present colporate pollen grains; $P$. outimouta is the only to have syncolporate pollen grains. Species of both genera present heteromorphism in the number of apertures. Excepting P. outimouta whose pollen grains are psilate, all species in the two genera present supratectal processes (gemmae/clavae), however the exine in the two genera are different-semitectate, reticulate in Bauhinia species, and tectate, rugulate (or psilate) in Phanera ones. Pollen characters support the segregation of Phanera from Bauhinia.
\end{abstract}

Keywords: Pollen Flora; Leguminosae; Cercideae; Taxonomy

\section{Introduction}

The family Leguminosae includes about 727 genera and 19,325 species, with cosmopolitan distribution and enormous economic importance [1]. It is one of the most diverse families in most neotropical vegetation types, especially in the seasonally dry tropical forests [2]. It presents great morphological variation in both macro- and micro-morphological traits, including characters derived from pollen grains [1]. The subfamily Caesalpinioideae is a paraphyletic grade of 171 genera and approximately 2250 species from which derived the monophyletic subfamilies Mimosoideae and Papilionoideae. The Caesapinioideae are currently divided into four tribes: Cercideae, Detarieae, Cassieae, and Caesalpinieae [1].

The tribe Cercideae is supported as monophyletic and has been found to be the most basal lineage within Leguminosae based on multiple datasets [3]. Members of the tribe are easily recognised by the morphology of their leaves, which present an entire or bilobed blade with three to many major veins. Wunderlin et al. [4] recognised two subtribes: Cercidinae (including the genera Cercis L., Adenolobus (Harvey ex Benth. \& Hook.) Torre \& Hillc., and Griffonia Baill.) and Bauhiniinae (including the genera Brenierea Humbert and Bauhinia L.). According to the Wunderlin et al. classification [4], only species of the genus Bauhinia are native to the Neotropics. Lewis and Forest [5], based on an unpublished phylogenetic analysis, adopt a narrower circumscription of Bauhinia, segregating the genera Barklya F. Muell., Gigasiphon Drake, Lasiobema (Korth.) Miq., Lysiphyllum (Benth.) de Witt., Phanera Lour., Piliostigma Hochst., and Tylosema (Schweinf.) Torre \& Hillc.

Vaz [6] has surveyed 98 species of Bauhinia (s.l.) in Brazil, classified in the sections Amaria (S. Mutis) Endl., Bauhinia, Benthamia Fortunato \& Wunderlin, Caulotretus DC., Pauletia (Cav.) DC., and Schnella (Raddi) Benth. In the State of Bahia, Lewis [7] recorded 34 species. Queiroz [8], who adopts the taxonomic propositions of [5], has described one species of Phanera and has transferred to that genus three species native to the caatinga thatwere formerly classified in Bauhinia. In a survey of the legumes of the caatinga, [8] recorded twelve species of Bauhinia and four of Phanera.

Pollen of the most Leguminosae species is characterised as monad, tricolporate and reticulate; this is a very common pollen type among more derived angiosperms [9]. However, dyads, tetrads, and polyads with varied numbers of pollen grains can be found among different genera of the family $[9,10]$. Caesalpinioideae pollen grains follow the general pattern of pollen morphology in 
the family, with single pollen grains [9].

The pollen of Bauhinia species has a tectate exine and is usually shed in monads. The tectum may present a (micro-)reticulate, striate, verrucate, or rugulate surface or a combination of these ornamentation features [11]. According to some authors [11-13], the more notable pollen characters of the genus Bauhinia are the gemmae and verrucae in several sizes and patterns of distribution on the tectum, in addition to the organisation of the reticulum.

Ferguson and Banks [13] cite the occurrence of tetrahedral tetrads in Bauhinia, with perforate tectum and small verrucae in the contact walls of the pollen grains. Such tetrads occur in only two species of the genus, $B$. phoenicea G. Don and B. pottsii Heyne; tetrads can be considered to be a derived character in the genus, because of their limited occurrence [13].

As described above, previous pollen studies in the genus Bauhinia (s.l.) disclose great variation in the pollen morphological features: ornamentation, apertures, and units of dispersal. Thus, Bauhinia is a eurypalynous taxon. This morphological diversity makes it possible to utilise pollen characters in phylogenetic and taxonomic studies of the genus.

This paper presents a survey of the pollen of the species of Bauhinia and Phanera native to the caatinga biome in northeastern Brazil, aiming to assess the implications of pollen morphology for the taxonomy of the group.

\section{Material and Methods}

The inventory of Bauhinia and Phanera species that occur in the caatinga was based on the work of [8]. All species cited by that author were surveyed, except for $B$. dubia G. Don, for which suitable material was not available. Specimens were taken from the collections of the ALCB, CEPEC, HRB, and HUEFS herbaria, acronyms according [14] (Table 1). Whenever possible, the polliniferous material was taken from specimens collected in caatinga vegetation.

Polliniferous material (floral buds and flowers) was prepared for light microscopy (LM) according to the $\mathrm{KOH}$ method of Faegri and Iversen [15]. The traditional acetolysis method of Erdtman [16] was not used, due to the fragility of the exine found in some species. Pollen slide preparations have been incorporated into the Palynotheca of the Universidade Estadual de Feira de Santana (PUEFS).

Whenever possible, three specimens of each species were studied. For each specimen, measurements of polar and equatorial diameter (in equatorial view) or equatorial diameter (in polar view) were taken from 25 pollen grains. In addition, the thickness of the exine and the height and width of ten gemmae were measured from ten pollen grains in each specimen. The ratio between sexine and nexine thickness was assessed qualitatively.

Untreated pollen grains for scanning electron microscopy (SEM) were taken from the anthers and put on sticky carbon tape on a stub. The prepared stubs were coated with gold using an SCD 050 sputter coater. The pollen grains were examined with a LEO 1430 VP JSM microscope, and images were digitally recorded.

Descriptions of pollen grains follow the terminology of Punt et al. [17]. Pollen size classes follow Erdtman [18].

\section{Results}

\subsection{General Pollen Morphology}

The pollen grains of the caatinga species of Bauhinia and Phanera are medium to very large in size (medium $=25$ $50 \mu \mathrm{m}$; large $=50-100 \mu \mathrm{m}$; very large $\geq 100 \mu \mathrm{m})$ and peroblate to subprolate in shape. The amb is circular (Figure 6(D)) or (sub-)triangular (e.g. Figures 1(I); 2(D), (I); 5(H), (K); 6(B), (K)) to polygonal (e.g. Figures 1(F); 2(B); 4(B)), with zonoapertures (pori, colpi and colpori). Pollen grains of Phanera species are smaller than those of Bauhinia, not exceeding $80 \mu \mathrm{m}$ in P. trichosepala, whose pollen grains are the largest in the genus. Among Bauhinia species, pollen grain diameter can reach more than $160 \mu \mathrm{m}$ in B. pentandra (Table 2). Most species have angulaperturate pollen grains (e.g. Figures 1(B), (F); 2(K); 3(D), (I); 4(B); 5(B), (H), (K); 6(B), (I), (J)) whose size varies from medium (P. flexuosa, P. microstachya, and $P$. outimouta) to large (B. acuruana, $B$. catingae, B. bauhinioides, B. brevipes, B. cacovia, $B$. cheilantha, B. dumosa, B. forficata, and P. trichosepala) or very large (B. brevipes, B. catingae, B. cacovia, $B$. cheilantha, B. forficata, B. pentandra, B. pulchella, and B. subclavata) (Table 2).

Heteromorphism in pollen aperture number is apparent in some species. The ornamentation of the exine surface presents several patterns: psilate, rugulate, and (micro-) reticulate, with gemmiform and/or claviform supratectal processes (Figures 1-6).

\subsection{Apertures}

The basic number of apertures varies widely, from three (B. acuruana, B. brevipes, B. cheilantha, B. dumosa, B. pulchella, B. subclavata, P. flexuosa, $P$. microstachya, $P$. outimouta, and $P$. trichosepala) to five (B. bauhinioides and B. pentandra) or six (B. cacovia, B. catingae, and B. forficata). No species included in this survey presented inaperturate pollen grains.

Heteromorphism in the number of apertures can be observed within some species: 4-aperturate pollen grains 
Table 1. Species of Bauhinia L. and Phanera Lour. present in the Caatinga biome (Queiroz, 2009), their current classification (based on Wunderlin et al., 1987; Vaz \& Tozzi, 2003; Lewis \& Forrest, 2005), and the vouchers for the present study.

Taxon $\quad$ Vouchers

Bauhinia L.

Sect. Pauletia (Cav.) DC.

Ser. Cansenia (Raf.) Wunderlin, Larsen \& Larsen

B. acuruana Moric.

B. brevipes Vogel

B. cheilantha (Bong.) Steud.

B. dumosa Benth.

B. pulchella Benth.

B. subclavata Benth.

Ser. Aculeatae Vaz. \& Az.-Tozzi

B. catingae Harms

B. cacovia [sp. ined. proposed by R. Wunderlin]

B. forficata Link

Ser. Pentandrae Wunderlin, Larsen \& Larsen

B. pentandra (Bong.) Vogel ex Steud.

Ser. Perlebia (Mart.) Wunderlin, Larsen \& Larsen

B. bauhinioides (Mart.) Macbr.

L.P. Queiroz 2017, Barreiras-BA, 01.XI.1987; M.L. Guedes et al. 6796, Formosa do Rio Preto-BA, 02.II.2000; L.P. Queiroz 5824, Bom Jesus da Lapa-BA, 10.II.2000.

L. Coradim 6351, Bom Jesus da Lapa-BA, 02.VII.1983; L. Coradim 7597, Barreiras-BA, 19.VI.1987; R.F. Vieira et al. 1887, Jataí-GO, 05.VII.1994.

Grupo Pedra do Cavalo 356, Conceição de Feira-BA, VII.1980; L.P. Queiroz 6551, Glória-BA, 26.IV.2001; S. Atkins PCD 5087, Rio de Contas-BA, 05.II.1997.

T.B. Cavalcanti 1583, Niquelândia-GO, 22.VII.1995; L.M.C. Gonçalves 185, Campo Formoso-BA, 04.IX.1991; R.C. Forzza 1628, Alto Paraíso-GO, 01.VIII.2000.

R.M. Harley et al. 50106, Abaíra-BA, 19.XII.1991; F. França et al. 1307, Abaíra-BA, 09.VII.1995; R. Mello-Silva et al. 453, Grão-Mogol-MG, 13.VI.1991.

M. Correia 436, Pesqueira-PE, 17.V.1995; L.P. Queiroz 3856, Santa Terezinha-BA, 26.VI.1994; F. França et al. 1922, Itatim-BA, 26.X.1996.

G. Hatschbach et al. 65975, Macaúbas-BA, 19.I.1997; M.M. Silva et al. 285, Maracás-BA, 26.II.2000; L.P. Queiroz et al. 3034, Santa Terezinha-BA, 29.XII.1992.

R.M. Harley 5871, Rio de Contas-BA, 16.II.1997; L.P. Queiroz 3870, Boa Vista do Tupim-BA, 26.IV.1994.

Grupo Pedra do Cavalo 930, Ipuaçú-BA, XI.1980; L.P. Queiroz 2322, Campinas-SP, 11.IV.1989; G.C.P. Pinto HUEFS 01513, Mundo Novo-BA, VIII.1972.

L.M. Cordeiro et al. 295, Canindé do São Francisco-SE, 04.XII.2000; M.L. Guedes 7942, Ipupiara-BA, 26.I.2001; G.C.P. Pinto 56/86, Cruz das Almas-BA, 18.VIII.1986.

A.M.A. Amorim et al. 1789, Jacobina-BA, 26.X.1995.

Phanera Lour.

Bauhinia sect. Caulotretus DC. [not combined in Phanera]

P. outimouta (Aubl.) L.P.Queiroz

L. Coradin 8545, Brotas de Macaúbas - BA, 10.IX.1992; L.R. Noblick 2445, Camaçari-BA, 14.XII.1992.

Bauhinia sect. Schnella (Raddi) Benth. [not combined in Phanera]

P. flexuosa (Moric.) L.P.Queiroz

L.P.Queiroz: M.L.S. Guedes \& D.P. Filho 7834, Morpará-BA, 22.I.2001; G.P Lewis \& S.M.M. Andrade 1866, Brumado - BA, 21.III.1991.

J.G. Jardim et al. 1064, Itacaré-BA, 23.V.1997; G. Hatschbach 42116, Riachão das Neves-BA, 12.III.1979; M.M. Arbo et al. 7618, Brumado-BA, 21.I.1997.

E.B. Miranda 333, Formosa do Rio Preto-BA, 30.III.2000; W. Ganev 1754, Abaíra-BA, 27.XII.1992; G.C.P. Pinto 3981, Cruz das Almas-BA,

P. trichosepala L.P.Queiroz 04.II.1981. 


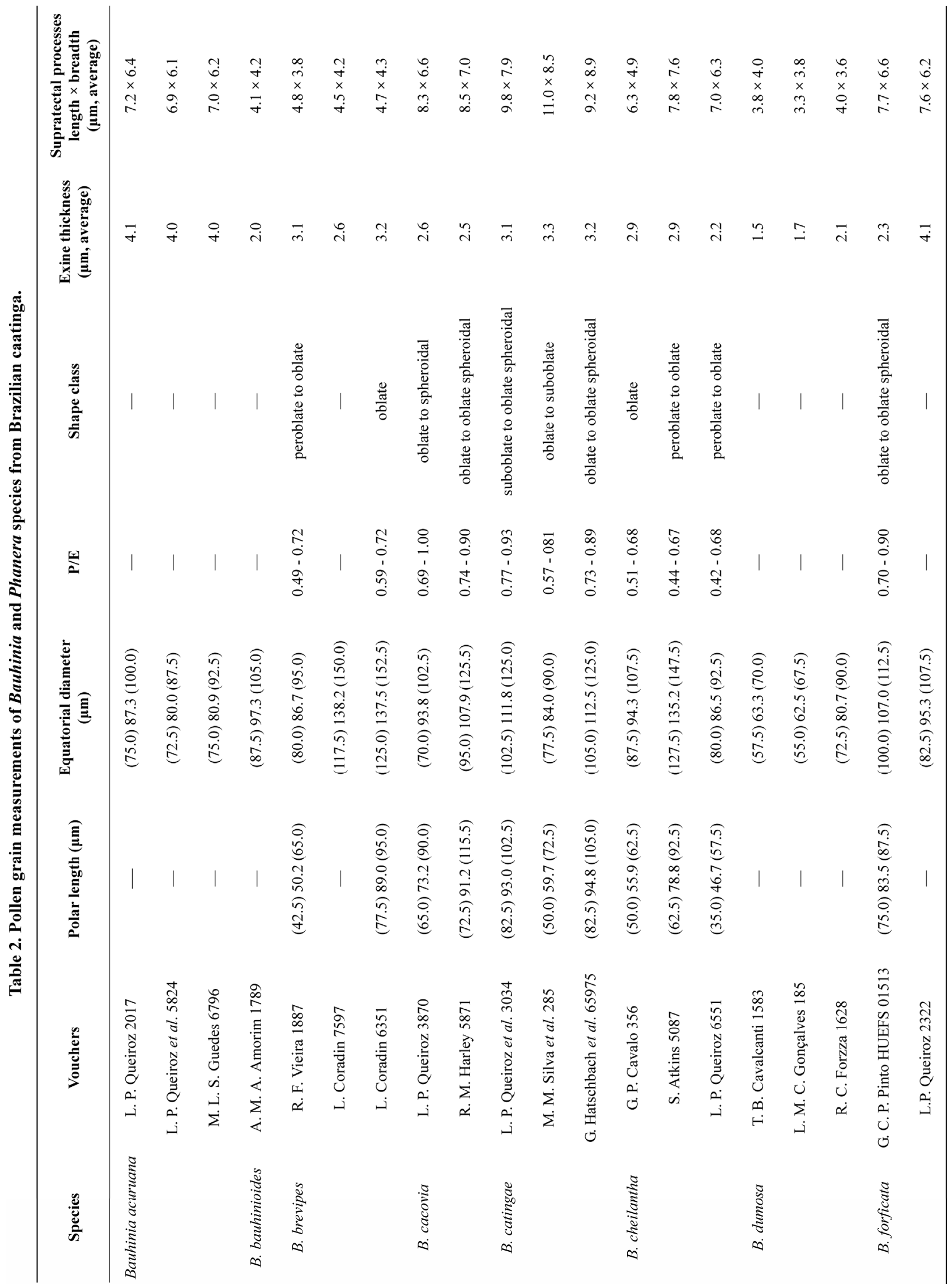




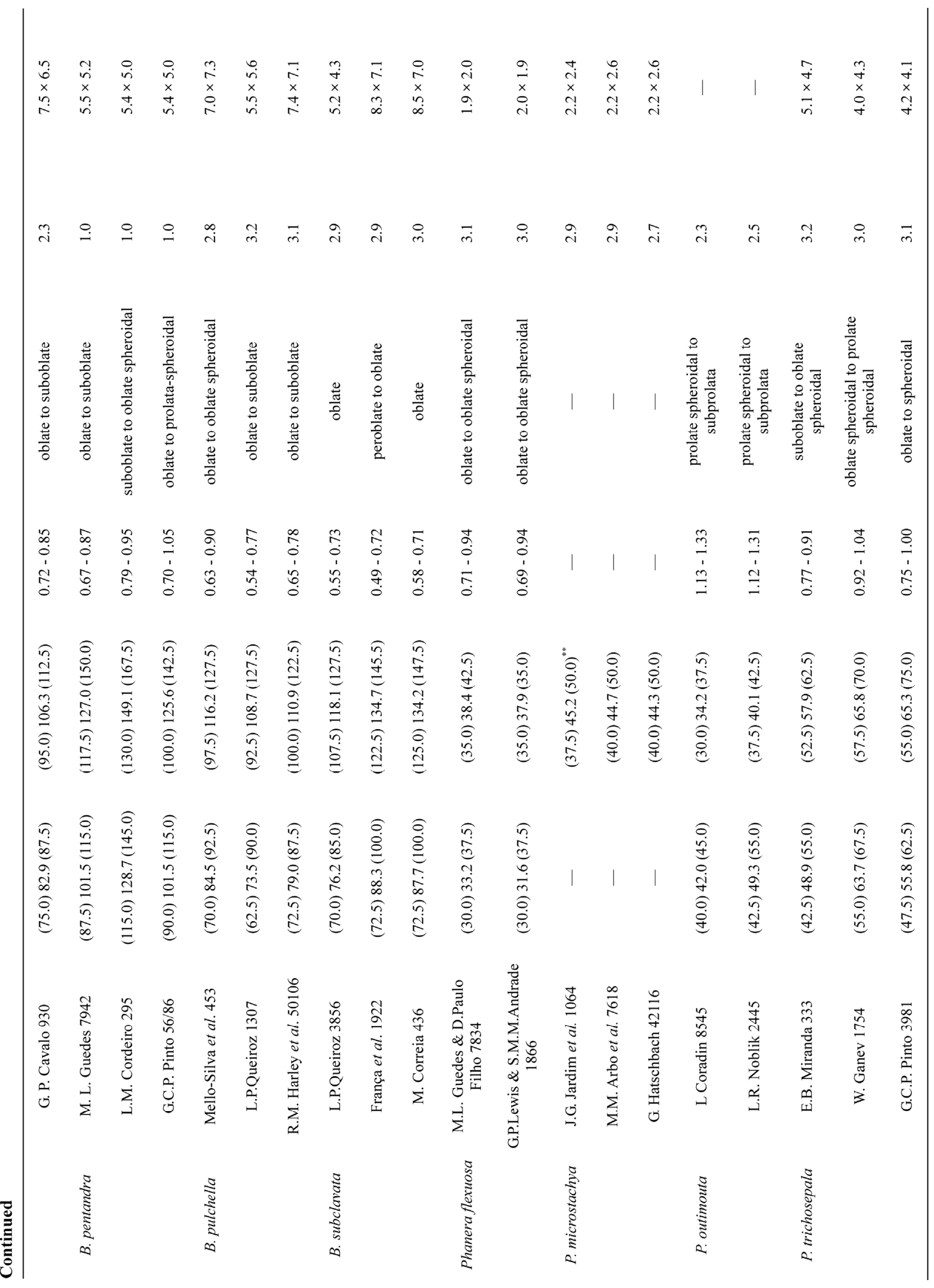


are found among the 3 -aperturate pollen of B. brevipes, $B$. flexuosa, B. pulchella, and P. trichosepala; 4-aperturate (in B. bauhinioides and B. pentandra) and/or 6-aperturate (in $B$. pentandra) pollen grains are found among typically 5-aperturate pollen; and 5-aperturate pollen grains are found among the 6-aperturate pollen of B. catingae.

Three types of apertures are found among the surveyed species. Colpate pollen grains are present in most of species of Bauhinia (Figures 2(C), (K); 3(B); 4(H), (I)), except in B. cheilantha and B. subclavata, whose pollen grains are porate (Figures 3(E); 5(I)). Among Phanera species, colporate pollen grains are the rule (Figures $\mathbf{5}(\mathbf{L}) ; \mathbf{6}(\mathbf{C}),(\mathbf{E}))$; pollen grains are syncolporate in most species except $P$. outimouta (Figure 6(F), (G)).

\subsection{Exine Structure and Surface}

The exine is thinnest in B. pentandra pollen grains, measuring around $1.0 \mu \mathrm{m}$ in thickness. B. acuruana presents the thickest exine, at least $4.0 \mu \mathrm{m}$ thick.

The columellae of B. cacovia, B. forficata, and B.

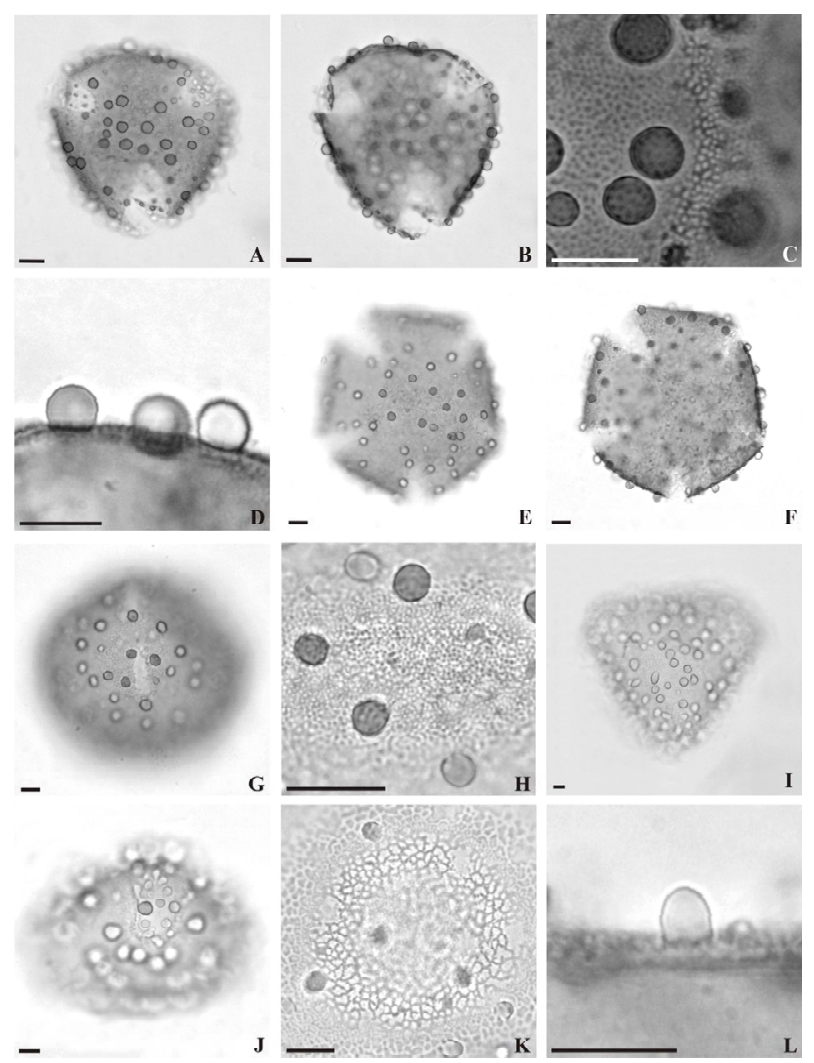

Figure 1. Pollen grains of Bauhinia spp. (A)-(D) B. acuruana: (A) Polar view, surface; (B) Polar view, optical section; (C) Detail of the ornamentation; (D) Detail of the gemmae. (E)-(H) B. bauhinioides: (E) Polar view, surface; (F) Polar view, optical section; (G) Equatorial view, surface; (H) Detail of the surface. (I)-(L) B. brevipes: (I) Polar view, surface; (J) Equatorial view, surface; (K) Detail of the surface; (L) Detail of the gemma. Scale bars: $10 \mu \mathrm{m}$. pentandra are heterogeneous in diameter, sometimes fused in the first of these species. Most Bauhinia species, however, present an exine with homogeneous, thin columellae.

In pollen grains of $P$. outimouta, the columellae layer is not seen under LM (Figure 6(D)); in other Phanera species, it is visible but appears diffuse.

Ectexine surfaces display in three basic ornamentation patterns among Bauhinia and Phanera species:

1) (micro-)reticulate, with supratectal processes (mainly gemmae and clavae) - this pattern is present on pollen grains of Bauhinia species (e.g. Figures 1(A), (C), (G), (H); 2(G)-(I); 3(A)-(C), (G); 4(H)-(J); 5(A), (E), (F));

2) psilate, without supratectal processes - this pattern is present only on pollen grains of Phanera outimouta (Figures 6(D)-(G));

3) rugulate and gemmate - this pattern is restricted to other species of Phanera (P. flexuosa, P. microstachya, and $P$. trichosepala), in which the tectum is irregularly rugulate with gemmae in different sizes (Table 2; Figures 5(J)-(L); 6(A)-(C), (H)-(L)).

The exine reticulum associated with supratectal processes (gemmae and clavae) is characteristic of Bauhinia species (Figures 1(H), (K); 2(F), (I), 3(G); 4(E), (J); 5(I)). However, the distribution of these supratectal elements is variable among these species. In most species, the pollen grains have regularly scattered gemmae and/or clavae, but in B. acuruana, B. pentandra, and B. pulchella they are irregularly scattered. Even the shape of these ornamentations varies; gemmae and clavae are present in most species, but verrucae are also observed on pollen grains of $B$. bauhinioides.

\subsection{Pollen Morphology of Species Examined}

\subsubsection{Bauhinia L.}

Bauhinia acuruana Moric. (Figures 1(A)-(D))-Pollen grains large, 3-colpate, angulaperturate; amb subtriangular to circular; colpi with diffuse outline, covered with a thin, slightly granulate membrane or with small gemmae on the membrane; exine reticulate, homobrochate, with many gemmae of different sizes irregularly scattered on the surface of the pollen grains, on some areas, gemmae are very close to each other, muri simplicolumellate, sinuous and sometimes discontinuous; with columellae homogeneous in diameter; sexine and nexine of equal thickness.

Bauhinia bauhinioides (Mart.) Macbr. (Figures 1(E)(H)) - Pollen grains large, 5(4)-colpate, zonoaperturate; amb subcircular to polygonal; colpi defined, with round ends, covered with a smooth to slightly granulate membrane; exine microreticulate, homobrochate, gemmae and verrucae in several sizes and regularly scattered, muri sinuous, simplicolumellate; with columellae homogene- 
ous in diameter; sexine and nexine of equal thickness.

Bauhinia brevipes Vogel (Figures 1(I)-(L))-Pollen grains large to very large, 3(4)-colpate, angulaperturate, oblate; amb triangular to subtriangular; colpi diffuse, with a slightly granulate membrane or with small gemmae on the membrane; exine (micro-)reticulate, heterobrochate, with gemmae (mostly) and clavae regularly scattered; muri simplicolumellate, sinuous and sometimes discontinuous; columellae very thin; sexine about twice as thick as the nexine.

Bauhinia cacovia R. Wunderlin (ined.) (Figures 2(A)(I))-Pollen grains large to very large, 6-colpate, zonoaperturate, oblate to spheroidal; amb subcircular to polygonal; colpi defined, with acute to round ends, covered with a smooth to slightly granulate membrane; exine microreticulate, heterobrochate, with clavae (mostly) and gemmae regularly scattered; muri simplicolumellate, sinuous; columellae thin and heterogeneous in diameter, sometimes fused; sexine about twice as thick as the nexine.

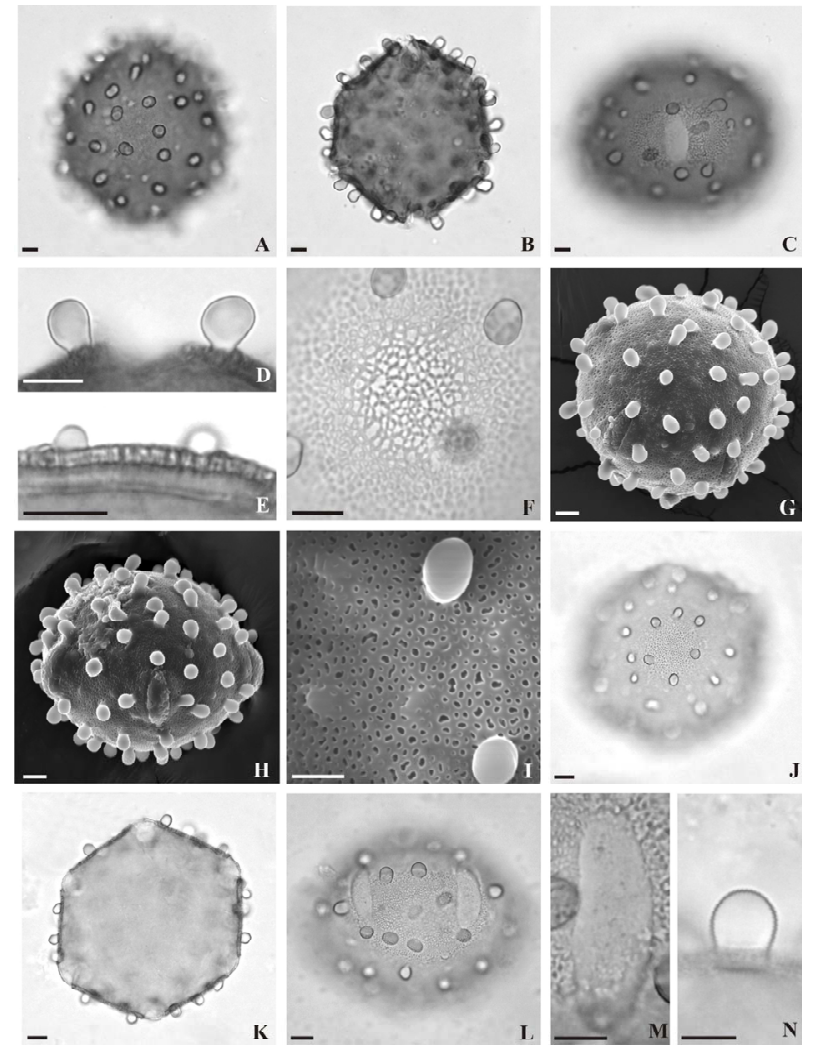

Figure 2. Pollen grains of Bauhinia spp. (A)-(I) B. cacovia: (A) Polar view, surface; (B) Polar view, optical section; (C) Equatorial view, surface; (D) Detail of the clavae; (E) Detail of the exine; (F) Detail of the surface; (G) Polar view (SEM); (H) Equatorial view (SEM); (I) Detail of the surface (SEM). (J)-(N) B. catingae: (J) Polar view, surface; (K) Polar view, optical section; (L) Equatorial view, surface; (M) Detail of the aperture; (N) Detail of the gemma. Scale bars: $10 \mu \mathrm{m}$; except Figure (E) and (I), $5 \mu \mathrm{m}$.
Bauhinia catingae Harms (Figures 2(J)-(N); 3(A), (B)) -Pollen grains large to very large, 6(5)-colpate, zonoaperturate, oblate to oblate spheroidal; amb subcircular to polygonal; colpi defined, covered with a thin, smooth to slightly granulate membrane, with round ends; exine microreticulate, homobrochate to reticulate, heterobrochate; gemmae and clavae of different sizes regularly scattered on the tectum. Pollen grains of the specimen M.M. Silva et al. 285 possess mainly clavae with irregular distribution and thin colpi with acute ends. Muri sinuous, simplicolumellate; columellae homogeneous in diameter; seine about twice as thick as the nexine.

Bauhinia cheilantha (Bong.) Steud. (Figures 3(C)(G)) - Pollen grains large, 3-porate, angulaperturate, oblate; amb subtriangular; pori diffuse, with a thin granulate membrane and presenting small gemmae, some of these often fused in groups; exine microreticulate, homobrochate; clavae and gemmae in several sizes and regularly scattered; muri sinuous; columellae homogeneous in diameter; sexine about twice as thick as the nexine.

Bauhinia dumosa Benth. (Figures 3(H)-(I))-Pollen grains large, 3-colpate, angulaperturate; amb subcircular to subtriangular; colpi diffuse, with a thin granulate membrane and presenting small gemmae; exine microreticulate, homobrochate; gemmae in several sizes and regularly scattered; muri sinuous; columellae very thin; sexine a little thicker than the nexine.

Bauhinia forficata Link (Figures 4(A)-(E))-Pollen

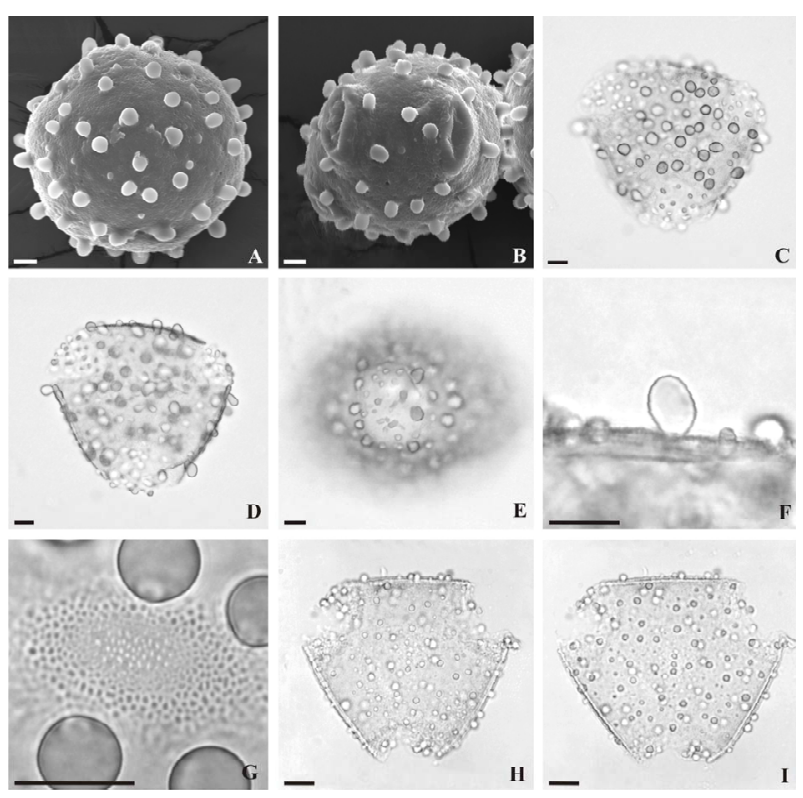

Figure 3. Pollen grains of Bauhinia spp. (A), (B) B. catingae: (A) Polar view (SEM); (B) Equatorial view (SEM). (C)-(G) B. cheilantha: (C) Polar view, surface; (D) Polar view, optical section; (E) Equatorial view; (F) Detail of the clava; (G) Detail of the surface. (H)-(I) B. dumosa: (H) Polar view, surface; (I) Polar view, optical section. Scale bars: $10 \mu \mathrm{m}$. 
grains large to very large, 6-colpate, zonoaperturate, oblate to oblate-spheroidal; amb circular to polygonal; colpi defined, with round ends; membrane (when visible) thin and granulate; exine microreticulate, homobrochate; clavae usually regularly scattered; muri simplicolumellate, sinuous; columellae heterogeneous in diameter; sexine about twice as thick as the nexine.

Bauhinia pentandra (Bong.) Vogel ex Steud. (Figures 4(F)-(J))-Pollen grains very large, 5(4,6)-colpate, suboblate to oblate spheroidal; amb subcircular to polygonal, mesocolpi flat or convex; colpi defined or diffuse, with round ends, covered with a slightly granulate membrane; exine microreticulate, homobrochate; gemmae in several sizes and irregularly scattered; muri simplicolumellate, sinuous; columellae thin and heterogeneous in diameter; sexine and nexine of equal thickness.

Bauhinia pulchella Benth. (Figures 5(A)-(F))-Pollen grains very large, 3(4)-colpate, angulaperturate, oblate to suboblate; amb subtriangular; colpi defined or diffuse, covered with a slightly granulate to reticulate membrane, with small gemmae; exine microreticulate, homobrochate; gemmae and clavae in several sizes and irregularly scattered; muri with supratectal processes smaller than the gemmae, sinuous and sometimes discontinuous; columellae diffuse; sexine about twice as thick as the nexine.

Bauhinia subclavata Benth. (Figures 5(G)-(I))-Pollen grains very large, 3-porate, oblate; amb subtriangular,

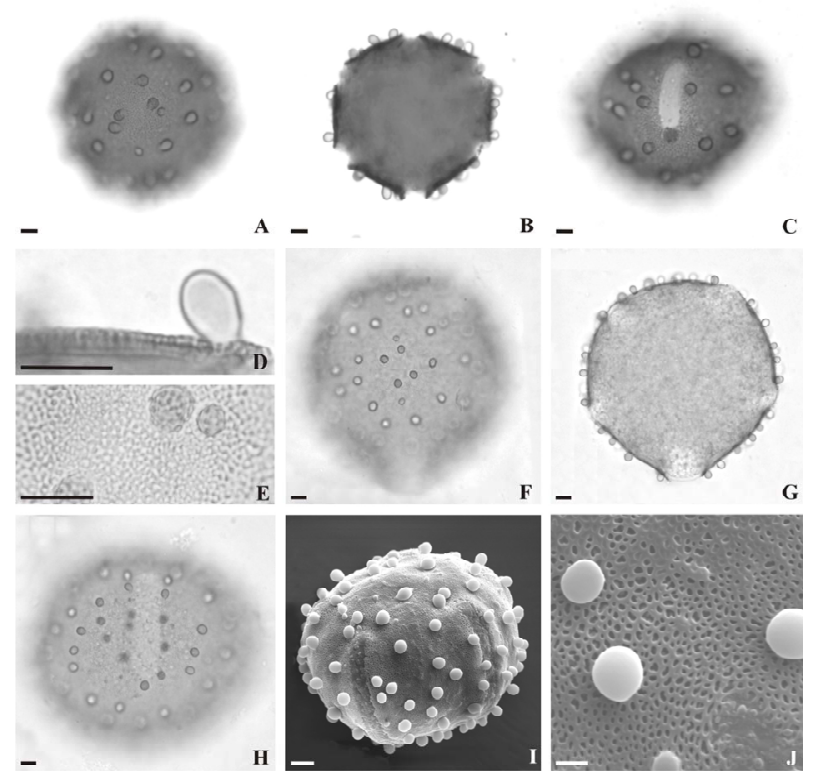

Figure 4. Pollen grains of Bauhinia spp. (A)-(E) B forficata: (A) Polar view, surface; (B) Polar view, optical section; (C) Equatorial view, surface; (D) Detail of the clava; (E) Detail of the surface. (F)-(J) B. pentandra: (F) Polar view, surface; (G) Polar view, optical section; (H) Equatorial view, surface (SEM); (I) Equatorial view, surface (SEM); (J) Detail of the surface (SEM). Scale bars: $10 \mu \mathrm{m}$; except Figure (J), $3 \mu \mathrm{m}$.

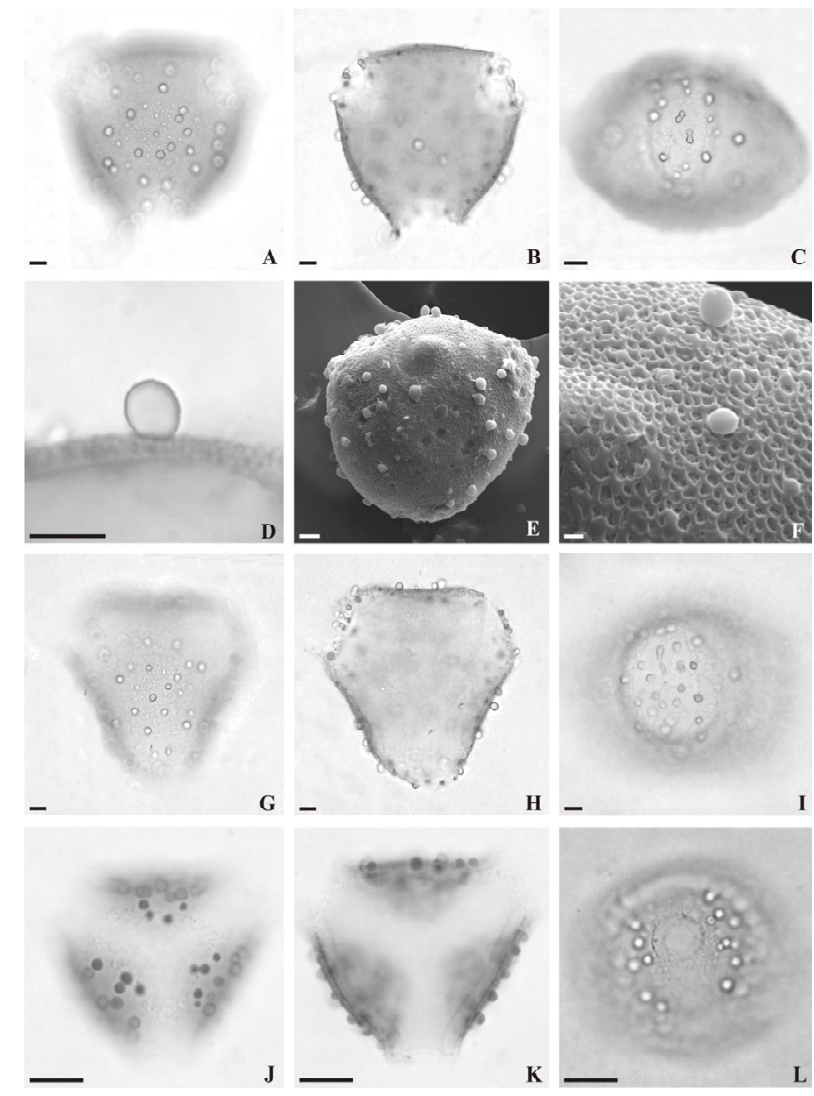

Figure 5. Pollen grains of Bauhinia spp. and Phanera spp. (A)-(F) B. pulchella: (A) Polar view, surface; (B) Polar view, optical section; (C) Equatorial view, surface; (D) Detail of the gemma; (E) Polar view, surface (SEM); (F) Detail of the surface (SEM). (G)-(I) B. subclavata: (G) Polar view, surface; (H) Polar view, optical section; (I) Equatorial view, surface. (J)-(L) P. flexuosa: (J) Polar view, surface; (K) Polar view, optical section; (L) Equatorial view, surface. Scale bars: $10 \mu \mathrm{m}$; except Figure (F), $2 \mu \mathrm{m}$.

mesopori slightly concave; pori with diffuse outline, covered with a slightly granulate or microgemmate membrane; exine microreticulate, heterobrochate; gemmae and clavae in several sizes and regularly scattered; muri simplicolumellate, sinuous, and discontinuous; columellae very thin; sexine about twice as thick as the nexine.

\subsubsection{Phanera Lour}

Phanera flexuosa (Moric.) L.P. Queiroz (Figures 5(J)(L) - Pollen grains medium-sized, 3(4)-syncolporate, and angulaperturate, oblate to oblate spheroidal; amb subtriangular; mesocolpi varying from flat to convex; ectoapertures long, with diffuse outline, with a slightly granulate membrane; endoapertures circular, bordered by a slight thickness of nexine (costa); exine diffusely rugulate under LM, with gemmae irregularly scattered; columellae diffuse; sexine a little thicker than the nexine.

Phanera microstachya (Raddi) L.P. Queiroz (Figures 6(A)-(C))-Pollen grains medium-sized, 3-syncolporate, 
angulaperturate; amb (sub-)triangular; ectoapertures defined or diffuse in some specimens, anastomosing at the pole (syncolporate), with a slightly granulate membrane; endoapertures circular or slightly lalongate, costate; exine rugulate, with gemmae in several sizes and irregularly scattered; columellae diffuse; sexine a little thicker than the nexine.

Phanera outimouta (Aubl.) L.P. Queiroz (Figures 6(D)(G) - Pollen grains medium-sized, prolate-spheriodal to subprolate, 3-colporate; amb circular; ectoapertures long, diffuse under LM and defined under SEM, with a slightly granulate membrane; endoapertures circular; exine slightly rugulate; collumellae not noticeable (under LM); sexine a little thicker than the nexine.

Phanera trichosepala L.P. Queiroz (Figures 6(H)-(L)) -Pollen grains large, 3(4)-syncolporate, angulaperturate, suboblate to oblate-spheroidal; amb circular to subtriangular; ectoapertures long, with diffuse outline, with a slightly granulate membrane; endoapertures circular,

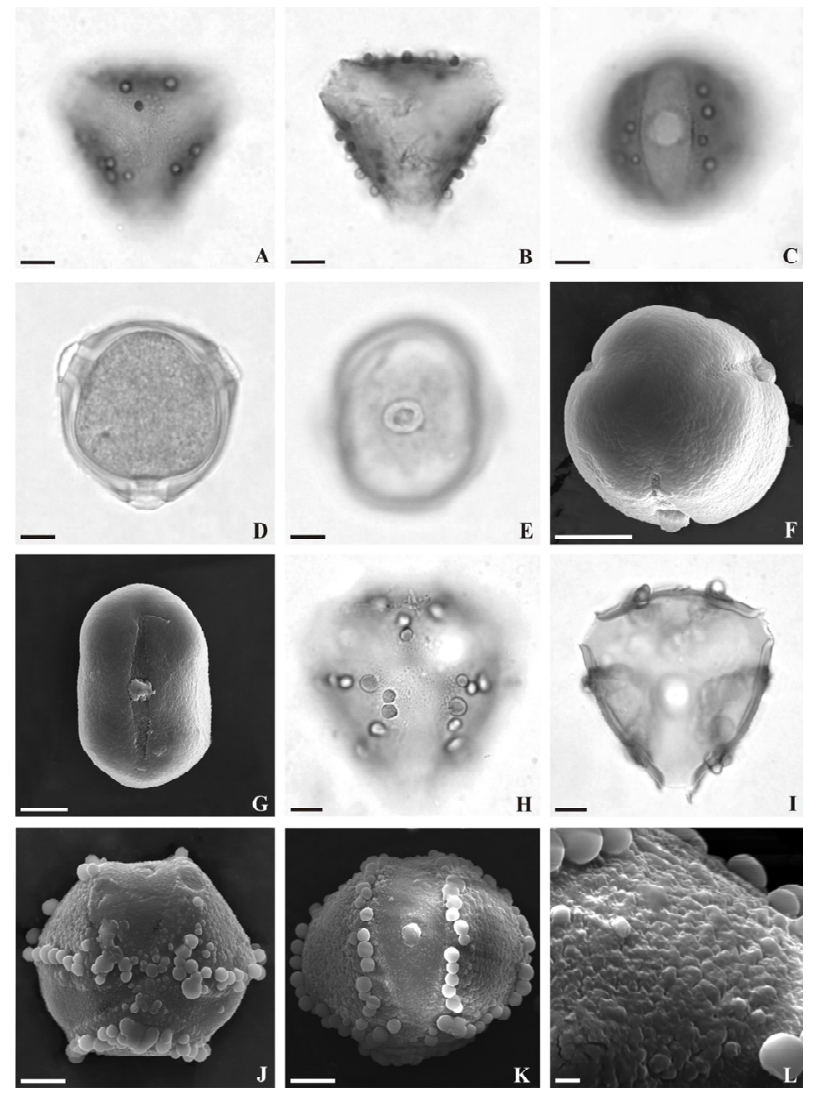

Figure 6. Pollen grains of Phanera spp. (A)-(C) P. microstachya: (A) Polar view, surface; (B) Polar view, optical section; (C) Equatorial view, surface. (D)-(G) P. outimouta: (D) Polar view, optical section; (E) Equatorial view, surface; (F) Equatorial view (SEM); (G) Polar view (SEM). (H)-(L) P. trichosepala: (H) Polar view, surface; (I) Polar view, optical section; (J) Polar view (SEM); (K) Equatorial view (SEM); (L) Detail of the exine (SEM). Scale bars: $10 \mu \mathrm{m}$; except Figure L, $2 \mu \mathrm{m}$. costate, narrower than the ectoapertures; exine rugulate, with gemmae bordering the ectoapertures; columellae diffuse; exine a little thicker than the nexine.

\subsection{Keys to Identification of the Pollen of the Genera and Species Examined}

A Pollen grains colpate or porate..................Bauhinia

A' Pollen grains colporate........................Phanera

\section{Bauhinia spp.}

1 Pollen grains monomorphic regarding the number of apertures........................................2

1' Pollen grains heteromorphic regarding the number of apertures..........................................6

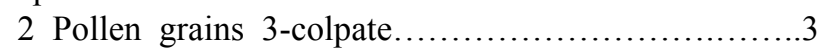

2 ' Pollen grains 6-colpate..........................5

3 Gemmae on apertural membrane....................4

3' Apertural membrane without gemmae......B. acuruana 4 Pollen grains porate.....B. cheilantha and B. subclavata 4' Pollen grains colpate........................... dumosa 5 Supratectal processes mostly claviform....... . forficata 5' Supratectal processes gemmiform................. cacovia 6 Pollen grains most frequently 3 -aperturate.............7

6 ' Pollen grains most frequently polyaperturate..........8

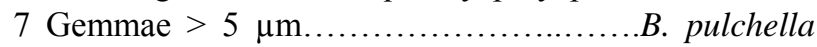

$7^{\prime}$ Gemmae $\leq 5 \mu \mathrm{m} \ldots \ldots \ldots \ldots \ldots \ldots \ldots \ldots .$. brevipes

8 Exine thickness $>2.0 \mu \mathrm{m} \ldots \ldots \ldots \ldots \ldots . . . . .$. . catingae

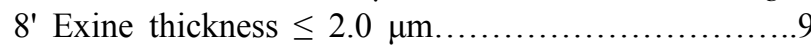

9 Pollen grains dimorphic (4-, 5-colpate)

9' Pollen grains trimorphic (4-, 5-, 6-colpate)

\section{Phanera spp.}

1 Pollen grains not syncolporate, psilate.....P. outimouta 1' Pollen grains syncolporate, with supratectal processes..........................................2 2 Pollen grains monomorphic regarding the number of apertures.......................... microstachya 2 ' Pollen grains heteromorphic regarding the number of apertures........................................... 3

3 Gemmae on all surfaces....................... flexuosa

3' Gemmae outlining the ectoaperture....P. trichosepala

\section{Discussion}

\subsection{Pollen Morphology of Bauhinia and Phanera}

The size range of pollen grains recorded here is consistent with that published by previous authors who have studied Bauhinia s.l. pollen grains [19-23]. Size differences among pollen grains are common within individuals of the same species (see Table 2). In both Bauhinia and Phanera, size is not a conservative pollen character at the species level.

Aperture type is a good character to unite species 
within both genera; apertures are colporate in Phanera species and colpate or porate in Bauhinia species.

\subsection{Apertures}

Variation in the number of apertures in different species of Bauhinia and Phanera was first recorded by VishnuMittre and Sharma [24], who described pollen types in Indian Bauhinia s.l. species ranging from inaperturate to 3-aperturate. Larsen [25] described pollen grains of Thai species ranging from inaperturate to 3-5-aperturate, and Ferguson and Pearce [21] found 3-7-zonoaperturate pollen grains in Neotropical species. Heteromorphism in aperture number has also been recorded in Bauhinia s.l. species by $[20,22]$.

In subgenus Bauhinia sensu [4], the species possess 3-7-colpate, colporoidate, or 5-7-porate pollen grains with an evenly varied sexine. According to [4], pollen grains are 3-7-colpate with supratectal elements in the series Cansenia and Perlebia (belonging to Bauhinia sect. Pauletia) within this subgenus. Such pollen morphology is consistent with that observed here for species in the corresponding section (B. catingae, B. forficata, and B. pentandra). In Bauhinia cheilantha and B. subclavata, however, the pollen grains present porate apertures with a length/breadth ratio less than two [17,23]. Therefore, Melhem and Salgado-Labouriau [19], when describing the pollen grains of B. bongardii Steud., preferred to use the term "apertural area" instead of using the concepts of colpus or porus. Buril et al. [23] also described pollen grains of $B$. acuruana and B. cheilantha as colpate and porate, respectively.

\subsection{Exine}

The presence of verrucae, gemmae, and clavae as elements of the ornamentation of the exine is a noticeable characteristic of the pollen morphology of the studied species of Bauhinia and Phanera. Reticulation of the exine supporting gemmiform or claviform processes has been recorded by authors who have studied the pollen grains of Bauhinia s.l. species [12,19,20,22,23]. However, these pollen features are not exclusive to Bauhinia. Thus, this ornamentation pattern is of limited utility at higher taxonomic levels among the Caesalpinioideae, within which it has appeared several times $[11,26]$.

According to [12], the general features of the of the pollen exine of Bauhinia s.l., together with the aperture patterns, place the genus as one of the most specialised within the subfamily Caesalpinioideae. However, most phylogenetic studies of the Leguminosae support the tribe Cercideae as the first diverging clade within the family [e.g., 3,27]. Hence, such specialised features of the exine should be regarded as recent acquisitions of Bauhinia s.l. within the Cercideae, rather than as ancient features of Leguminosae pollen grains.

All species of Bauhinia from caatinga present large flowers with white petals, nocturnal anthesis, and nectar produced inside a cylindrical-tubular hypanthium [8]. These features match the criteria presented by Faegri and van der Pijl [28] for the chiropterophily syndrome. Indeed, Arroyo [29] has reported that species of Bauhinia with such features are largely pollinated by bats. This has been subsequently confirmed by other pollination studies [30,31]. On the other hand, the caatinga species of Phanera have much smaller flowers with matutinal anthesis and a wider, campanulate hypanthium [8], and are probably pollinated by bees. Large supratectal processes in caesalpinioid legumes have been reported for the Amazonian genera Dicymbe Spruce ex Benth., Eperua Aubl., and Paloue Aubl. (tribe Detarieae) [11,32]. Species of these genera are largely pollinated by bats [29], which may suggest an association between this kind of ornamentation and adaptation to bat pollination. A corollary of this hypothesis is that the bee-pollinated genus Phanera, which largely presents the same supratectal processes, is derived from bat-pollinated ancestors and has retained this kind of ornamentation due to phylogenetic constraint. This intuitive hypothesis could be tested by a phylogenetic study of the Cercideae with a wide sampling of bee- and bat-pollinated species.

\subsection{Taxonomic Implications}

According to Vaz's classification [6], the Bauhinia species from caatinga are classified in the section Pauletia (Cav.) DC., series Aculeatae Vaz \& A.M.G. Azevedo (B. cacovia, B. catingae, and B. forficata), Cansenia (Raf.) Wunderlin, Larsen \& Larsen (B. acuruana, B. brevipes, B. cheilantha, B. dumosa, B. pulchella, and B. subclavata), Pentandrae Wunderlin, Larsen \& Larsen (B. pentandra) and Perlebia (Martius) Wunderlin, Larsen \& Larsen (B. bauhinioides).

Series Pentandrae is characterised by 3-7-colporate pollen [4]. However, the results presented here show 5(4, 6)-colpate pollen grains, which suggests a closer relationship with B. bauhinioides (series Perlebia). A close relationship between $B$. bauhinioides and B. pentandra has been proposed previously by [21], who grouped these species in a taxonomic complex called the "aculeata/ perlebia/pentandra-Alliance". According to these authors, this group is formed of species with 5-7-colpate pollen grains, which would include B. cacovia and $B$. catingae as reported here. The authors, however, included in this group Bauhinia cheilantha, which is characterised here by 3-colpate pollen grains.

Another group formed by Ferguson and Pearce [21] on the basis of pollen morphology is called the "CanseniaAlliance"; it includes the species B. acuruana, B. dubia, 
and B. brevipes. All species in this group were described as having pollen morphology consistent with the results presented here: pollen grains large, 3-colpate, microreticulate and with gemmae and/or clavae.

Vaz and Tozzi $[33,34]$ proposed the new Aculeatae, segregated from the series Cansenia sensu [4]. This series includes the caatinga species B. cacovia, B. catingae, and $B$. forficata. These species form a homogeneous group based on pollen features. B. catingae pollen differs from that of the other two species mainly by of aperture number heteromorphism.

The surveyed species of the genus Phanera from caatinga belong to the sections Caulotretus ( $P$. outimuota) and Schnella (P. flexuosa, P. microstachya, and P. trichosepala) in the classification of [4] for Bauhinia s.l. Species of this genus present exines with different ornamentation features. In the species formerly included in Bauhinia sect. Schnella, now placed in Phanera, the exine is rugulate with gemmae on the surface. However, the patterns of distribution of the supratectal processes differ between $P$. trichosepala and the group formed by $P$. flexuosa and P. microstachya. In the former species, gemmae are distributed only around the edges of the ectoapertures; in the other two, they are distributed heterogeneously on the surface. Ferguson and Pearce [21], studying New World species of Phanera (as Bauhinia s.l.), recorded pollen grains similar to those of sect. Schnella. Those authors also analyzed Phanera microstachya (as Bauhinia s.l.).

Phanera outimouta differs from the remaining caatinga species of Phanera by its psilate exine without supratectal processes. This species was classified in Bauhinia sect. Caulotretus by [4]. There are no previous records for $P$. outimouta $(=B$. outimouta $)$ in the pollen literature. The pollen features presented by $P$. outimouta match those reported by [21] for the "Caulotetrus-group": pollen grains that vary from prolate-spheroidal to subprolate, ectoapertures with length generally about twothirds of the polar axis, and characteristically circular endoapertures. The non-observation of the columellae layer under LM may indicate the presence of a granular infratectum, also cited by $[12,21]$ as characteristic of the group.

\section{Conclusions}

Many taxa of tribe Cercideae (subfamily Caesalpinioideae), including Bauhinia and Phanera, have been the subject of pollen studies in relation to taxonomy and systematics. Their characteristically gemmate exine has assumed an important role to pollen feature of both genera-even when they were merged into Bauhinia. We believe that pollen studies for the complete set of species of Bauhinia, including related genera such as Phanera, would provide secure data from which to assess the taxonomic relationship among genera and, furthermore, the relationship of pollen morphology and the pattern of pollination which has a great range of vectors, including bees, butterflies, birds and bats $[35,36]$.

Different positions about the taxonomy of Bauhinia s.l. are summarised in the revisionary works of [4] and [5]. Wunderlin et al. [4] adopt a wider circumscription of Bauhinia and divide this genus into 4 subgenera and 37 subsections and series. On the other hand, Lewis and Forest [5] split Bauhinia into nine different genera, of which Bauhinia and Phanera occur in the New World. Our results reinforce the distinction between Bauhinia and Phanera by the different aperture patterns found in the two groups: all surveyed species of Phanera present colporate apertures, while Bauhinia species have porate or colpate apertures.

Besides pollen data from Bauhinia and Phanera species will be helpful to studies on pollen dispersion by vectors including bats and hummingbirds in caatinga areas, where that scope of study is rare.

\section{Acknowledgements}

Thanks are due to the Conselho Nacional de Desenvolvimento Científico e Tecnológico (CNPq) for providing grants and financial support to research project; to Dr. Ângela Vaz for taxonomic comments; to the keepers of the ALCB, CEPEC, and HUEFS herbaria for specimens; to Mrs. Gisele Pinto Rocha for SEM assistance, and to Mrs. Neuza Magalhães Moraes Santos for Library assistance.

\section{REFERENCES}

[1] G. Lewis, B. Schrire, B. Mackinder and M. Lock, Eds., "Legumes of the World," Royal Botanic Garden, Kew, 2005.

[2] R. T. Pennington, M. Lavin, D. E. Prado, C. A. Pendry, S. K. Pell and A. C. Butterworth, "Historical Climate Change and Speciation: Neotropical Seasonally Dry Forest Plants Show Patterns of Both Tertiary and Quaternary Diversification," Philosophical Transactions of the Royal Society B: Biological Sciences, Vol. 359, 2004, pp. 515-537. doi:10.1098/rstb.2003.1435

[3] A. Bruneau, M. Mercure, G. Lewis and P. S. Herendeen, "Phylogenetic Patterns and Diversification in Caesalpinioid Legumes," Botany, Vol. 86, No. 7, 2008, pp. 697-718. doi:10.1139/B08-058

[4] R. P. Wunderlin, K. Larsen and S. S. Larsen, "Reorganization of the Tribe Cercideae (Fabaceae: Caesalpinioideae)," Biologiske Skrifter Kongelige Danske Videnskabernes Selskab, Vol. 28, 1987, pp. 1-40.

[5] G. Lewis and F. Forest, "Tribe Cercideae," In: G. Lewis, B. Schrire, B. Mackinder and M. Lock., Eds., Legumes of the World, Royal Botanic Garden, Kew, 2005, pp. 57-67. 
[6] A. M. S. F. Vaz, "Taxonomia de Bauhinia sect. Pauletia (Leguminosae: Caesalpinioideae: Cercideae) No Brasil," Ph.D. Thesis, UNICAMP, Campinas, 2001.

[7] G. Lewis, "Legumes of Bahia," Royal Botanic Garden, Kew, 1987.

[8] L. P. Queiroz, "Leguminosas da Caatinga," UEFS, Feira de Santana, 2009.

[9] P. H. Guinet, "Comparative Account of Pollen Characters in the Leguminosae," In: R. M. Polhill and P. H. Raven, Eds., Advances in Legume Systematics, Part 2, Royal Botanic Garden, Kew, 1981, pp.789-799.

[10] M. S. F. Silvestre-Capelato, "Palinologia das Leguminosae da Reserva Biológica do Parque Estadual das Fontes do Ipiranga (São Paulo, Brasil)," Ph.D. Thesis, UNICAMP, Campinas, 1993.

[11] A. Graham and G. Barker, "Palynology and Tribal Classification in the Caesalpinioideae," In: R. M. Polhill and P. H. Raven, Eds., Advances in Legume Systematics, Part 2, Royal Botanic Garden, Kew, 1981, pp. 801-834.

[12] I. K. Ferguson, "A Preliminary Survey of the Pollen Exine Stratification in the Caesalpinioideae," In: C. H. Stirton, Ed., Advances in Legume Systematics, Part 7, Royal Botanic Garden, Kew, 1987, pp. 355-385.

[13] I. K. Ferguson and H. Banks, "Tetrad Pollen in the Subfamily Caesalpinioideae (Leguminosae) and Its Significance," Review of Palaeobotany and Palynology, Vol. 83, No. 1, 1994, pp. 31-42. doi:10.1016/0034-6667(94)90055-8

[14] P. K. Holmgren and N. H. Holmgren, "Index Herbariorum," 2006. http://sciweb.nybg.org/science2/IndexHerbariorum.asp

[15] K. Faegri and J. Iversen, "Textbook of Pollen Analysis," Blackwell Sci. Publ., Oxford, 1975.

[16] G. Erdtman, "The Acetolysis Method. A Revised Description," Svensk Botanisk Tidskrift, Vol. 39, 1960, pp. 561-564.

[17] W. Punt, P. P. Hoen, S. Blackmore, S. Nilsson and A. Le Thomas, "Glossary of Pollen and Spores Terminology," Review of Palaeobotany and Palynology, Vol. 143, No. 2, 2007, pp. 1-81. doi:10.1016/j.revpalbo.2006.06.008

[18] G. Erdtman, "Pollen Morphology and Plant Taxonomy. Angiosperms," Almqvist and Wiksell, Stockholm, 1952.

[19] T. S. Melhem and M. L. Salgado-Labouriau, "Pollen Grains of Plants of the Cerrado-V: Leguminosae, Caesalpinioideae," Revista Brasileira de Biologia, Vol. 23, 1963, pp. 369-387.

[20] A. Schmitz, "Contribuition Palynologique a la Taxonomie des Bauhinieae (Caesalpinaceae)," Bulletin du Jardin Botanique National de Belgique, Vol. 43, 1973, pp. 369423. doi: $10.2307 / 3667620$

[21] I. K. Ferguson and K. J. Pearce, "Observation on the Pollen Morphology of the Genus Bauhinia L. (Leguminosae: Caesalpinioideae) in the Neotropics," In: S. Blackmore and I. K. Ferguson, Eds., Pollen and Spores: Form and Function, Academic Press, London, 1986, pp. 283-296.

[22] J. C. Gamerro and R. H. Fortunato, "Morfologia del Polen de las Especies Argentinas de Bauhinia (Cercideae,
Caesalpinioideae, Fabaceae)," Annals of Missouri Botanic Gardens, Vol. 88, 2001, pp. 144-158.

doi: $10.2307 / 2666135$

[23] M. T. Buril, M. Alves and F. A. R. Santos, "Tipificação Polínica em Leguminosae de uma Área Prioritária para Conservação da Caatinga: Caesalpinioideae e Papilionoideae," Acta Botanica Brasilica, Vol. 25, No. 3, 2011, pp. 722-739. doi:10.1590/S0102-33062011000300023

[24] Vishnu-Mittre and B. D. Sharma, "Studies of Indian Pollen Grains," Pollen et Spores, Vol. 4, No. 1, 1962, pp. 5-45.

[25] S. S. Larsen, "Pollen of Thai Species of Bauhinia," Grana, Vol. 14, 1975, pp. 114-131. doi:10.1080/00173137409429902

[26] M. D. Crisp and P. H. Weston, "Mirbelieae," In: M. D. Crisp and J. J. Doyle, Eds., Advances in Legume Systematics, Part 7, Royal Botanic Garden, Kew, 1995, pp. 53-61.

[27] M. F. Wojciechowski, M. Lavin and M. J. Sanderson, “A Phylogeny of Legumes (Leguminosae) Based on Analysis of the Plastid matK Gene Resolves Many Well-Supported Subclades within the Family," American Journal of Botany, Vol. 91, No. 11, 2004, pp. 1846-1862. doi:10.3732/ajb.91.11.1846

[28] K. Faegri and L. van der Pijl, "The Principles of Pollination Ecology," Pergamon Press, Oxford, 1971.

[29] M. T. K. Arroyo, "Breeding Systems and Pollination Biology in Leguminosae," In: R. M. Polhill and P. H. Raven, Eds., Advances in Legume Systematics, Part 2, Royal Botanic Garden, Kew, 1981, pp. 723-769.

[30] R. E. Heithaus, E. Stashiko and P. K. Anderson, "Cumulative Effects of Plant-Animal Interactions on Seed Production by Bauhinia ungulata, a Neotropical Legume," Ecology, Vol. 63, No. 5, 1982, pp. 1294-1302. doi: $10.2307 / 1938857$

[31] N. Muchhala and P. V. Jarrín, "Flower Visitation by Bats in Cloud Forest of Western Ecuador," Biotropica, Vol. 36, 2005, pp. 387-395.

[32] H. Banks and L. Rico, "Pollen Morphology and Phylogenetic Analysis of Eparua Aublet (Detarieae: Caesalpinioideae: Leguminosae)," Grana, Vol. 38, 1999, pp. 261-276.

[33] A. M. S. F. Vaz and A. M. G. A. Tozzi, "Aculeatae, a New Series in Bauhinia Section Pauletia (Leguminosae, Caesalpinioideae, Cercideae)," Novon, Vol. 13, 2003, pp. 141-144. doi: $10.2307 / 3393579$

[34] A. M. S. F. Vaz and A. M. G. A. Tozzi, "Bauhinia ser. Cansenia (Leguminosae: Caesalpinioideae) no Brasil," Rodriguésia, Vol. 54, 2003, pp. 55-143.

[35] O. Hokche and N. Ramírez, "Pollination Ecology of Seven Species of Bauhinia (Leguminosae: Caesalpinioideae)," Annals of Missouri Botanic Gardens, Vol. 77, No. 3, 1990, pp. 559-572. doi:10.2307/2399520

[36] A. Stroo, "Pollen Morphological Evolution in Bat Pollinated Plants," Plant Systematic and Evolution, Vol. 222, No. 1-4, 2000, pp. 225-242. doi:10.1007/BF00984104 